\title{
Mites associated with stored products
}

\author{
A.M Metwally ${ }^{1}$; A.A.AbdAllah ${ }^{1}$; Hala,M.Gamal El- Din ${ }^{2}$ and Hala,M. El-Bltagy ${ }^{2}$ \\ ${ }^{1}$ Agric. Zoology and Nematology Dept. Faculty of Agriculture, Al - Azhar University. \\ ${ }^{2}$ Biological and Environmental Science Dept. Faculty of Home Economic, Tanta, Al- Azhar University. \\ Corresponding author: Awadabdallah28@yahoo.com
}

\begin{abstract}
This work was conducted to incidence the mites associated with stored products during the two successive years (2013 and 2014). Fifty two mite species from fifteen different stored product; wheat, rice, bean, maize, garlic, hay, onion, corn, pea, bread bean, animal feed, seeds, flour, grain barley and faba bean were collected from two governorates Gharbia and Cairo. The collected mites belonging to 2 orders, 4 suborders and 23 families. Suborder Gamasida included 16 species of 7 families; suborder Actinedida included 16 species of 9 families ;suborder Acaridida included 19 species of 6 families; suborder Oribatida included 1 species of 1 family.
\end{abstract}

Key words: Incidence, Mites, stored products

\section{Introduction}

Stored product mites play an important role in human life. In many cases they caused serious economic loss or health problems. Mites inhabited mainly the stored food, plant material and debris. In stored plant grain and oilseeds the mites' infestations were studied intensively. Among the next commodities well documented are the mite infestation in cereal based food, dried fruits, root crops and ornamentals, and chesses (Hughes, 1976). Mites are a major cause of qualitative and quantitative losses to several stored products. The pest importance of stored product mites has been reviewed and three pest risks are suggested; (i) direct consumption on human food, animal feed or other products changing the quality of infested products, they can penetrate the hard grains and feed directly on the grain kernels, therefore they destroy their germination power, change the moisture contents of medius, initiating growth and spread mould, (Sinha and Wallace, 1977; Taha, 1985; Gulati and Mathur, 1995); (ii) interaction to microorganisms leading to the transfer of mycotoxins production fungi or pathogenic bacteria; (iii) production of hazardous compounds among them the allergens are of the highest importance.

\section{Materials and Methods}

\section{The sampling procedure}

The present investigation tended to record the different mite species associated with the different stored products bring from different districts at Gharbia and Cairo governorates. The samples of stored food products were picked and singly kept in tightly closed polyethylene bags. A label including all necessary information concerning habitat, locality and date of collection were stuck on each bag and then, transferred to the laboratory. A sample of 250 gm from each material was isolated by modified Tullgren funnels, in $3 \mathrm{~cm}$ deep layers and kept for 24 hours below 40watt electric lamps. The mites were collected into petri- dishes with aring of Vaseline mixed with citronella oil to prevent mite escape (Metwally, 1976). Active mite individuals were transferred by $0.3 \mathrm{~mm}$ camel hair brush and examined using stereomicroscope.

Isolated speciemens were placed in Nesbiti solution (Krantz and Walter, 2009) (40 gm chloral hydrate, $25 \mathrm{ml}$ distilled water and $2.5 \mathrm{ml}$ concentrated hydrochloric acid) for 24 hours, then mounted by placing a drop of Hoyer's medium (Hughes, 1976; Krantz and Walter, 2009) Individual mite was pressed carefully to the botton of the droplet and arranged using a cleen pair of forceps, a cover slip was picked up at its edge, applied the opposite edge to the edge of the Hoyer's droplet to allow the cover slip to fall into its place, then, mounted slide was placed on hot plate at $40-50{ }^{0} \mathrm{c}$ for 2-4 days (Krantz, 1978; EL- Sanady, 2005).

Identification, the specimens were identified and kept on the mite collection of Agric, Zoology, Nematology Department Faculty of Agric. ALAzher University. Identification was carried out according, Griffiths, (1960); Lindqust and Evans, (1965); Hughes, (1961-1976); Summer and Price, (1970); Zaher et al., (1984); Krantz and Walter, (2009).

\section{Results and Discussion}

\footnotetext{
- Incidence of mites associated with stored products

Mites of stored products were recorded during the two successive years (2013 and 2014). The collected mites belonging to both orders: Parasitiformes and Acariformes.
} 


\section{Order Parasitiformes}

Obtained results are presented in Table (1). This order was represented by suborder Gamasida which included seven families: Ascidae, Ameroseiidae, Rhodacaridae, Digamaseilidae, Ologamasidae, Macrochelidae, and Parasitidae. These families have sixteen species belong to nine genus.

\section{Family Ascidae}

Many investigators recordcd some species belonging to family ascidae associated with pests infesting stored products (Hughes, 1976; Taha, 1985). This family was represented by eight species; the first three species belong to genus Proctolaelaps. The first species was Proctolaelaps pygmaus, which was isolated from wheat and maize collected from Nawag and Sammanoud by rare numbers. Also, Proctolaelaps bickley, was isolated from garlic and bread bean collected from Nawag and Sammanoud by rare numbers. The third speies was Proctolaelaps cossi, which was isolated from animal feed and seeds collected from Nawag and Kafr El-Hema by rare numbers.

The second three species belong to genus Lasioseius Lasioseius africanus, was isolated from wheat, floor and rice collected from Nasr City and Nawag by intermediate numbers. Lasioseius sewai, was isolated from onion, corn and pea collected from Nawag and Sammanoud by rare numbers. Lasioseius aegypticus was isolated from wheat and grain collected from Nawag and Nasr City by few numbers. The last two species belong to genus Blattisocius the first species was Blattisocius keegani, was isolated from barley and faba bean collected from Nawag, Sammanoud and Nasr City by few numbers. The second one Blattisocius tarsalis, was isolated from barley, grain and seeds collected from Nawag and Kafr El-Hema by few numbers. All Ascidae mite species were recorded through the year.

\section{Family Ameroseiidae}

This family was represented by two species Kleemania kossi, which was isolated from corn, onion and garlic collected from Nawag and Sammanoud by rare numbers. Also, Kleemania plumosus, was isolated from onion, maize and bread bean collected from Nawag and Sammanoud by few numbers during the two successive years.

\section{Family Rhodacaridae}

This family was represented by one species Rhodacarus tabeeni, which was isolated from onion, rice and bean collected from Nasr City and Nawag by rare numbers during the two successive years.

\section{Family Digamaseilidae}

This family was represented by two species Dendrolaelaps aegypticus, which was collected from rice, wheat and barley from Nasr City, Sammanoud and Kafr El-Hema by rare numbers during the summer season 2014. Dendrolaelaps rasmii, which was isolated from animal feed and collected from Nasr City and Nawag by rare numbers.

\section{Family Ologamasidae}

This family was represented by one species Gamasiphis pulchellus, which was isolated from pea, rice and faba bean collected from Sammanoud and Nawag only by a few number during summer season 2014.

\section{Family Macrochelidae}

The family Macrochelidae was represented by one species Macrocheles scutatus, which was inhabiting animal feed collected from Nawag and Kafr El-Hema by few numbers during the summer season 2014.

\section{Family Parasitidae}

This family included one species Parasitus consoginues, which isolated from animal feed and maize collected from Nawag by a few number during the whole year of 2014 .

\section{Order Acariformes}

Obtained results are presented in Table (2 and 3). This order was repredented by three suborder Actinidida, Acaridida and Oribatida.

A - Suborder Actinidida which included sixteen species, fourteen genus of nine families Pyemotidae, Acarophenacidae, Pygmophoridae, Scutacaridae, Bdellidae, Cunaxidae, Tarsonemidae, Cheyletidae and Stigmaeidae as show in (table 3).

B-Suborder Acaridida which included nineteen species, eleven genus of six families Acaridae, Suidasidae, Carpoglyphidae, Glycyphagidae, Labidophoridae and Chortoglyphidae as show in (table 2).

C - Suborder Oribatida which included one species of one family Oppiidae as show in (table 3).

\section{A - Suborder Actinidida}

Obtained results are presented in Table (3).

\section{Family Pyemotidae}

This family was represented one species Pyemotis herfisi, which was isolated from grain and faba bean collected from Nawag and Kafr El-Hema by dominant numbers during all the period of the study.

\section{Family Acarophenacidae}

This family was included one species Acarophenax sp., which was isolated from rice, wheat and bean collected from Sammanoud by rare numbers during the whole year of 2014.

\section{Family Pygmophoridae}

This family was included one species Pediculaster sp., which was isolated from onion and 
hay collected from Nawag and Sammanoud by rare numbers during summer seasons.

\section{Family Scutacaridae}

This family included one species Scutacarus sp., which was isolated from animal feed collected from Nasr City by rare numbers during the both summer seasons.

\section{Family Bdellidae}

The family Bdellidae was represented by one species Spinibdella bitoreata, which was isolated from animal feed and rice collected from Nawag by rare numbers during the whole year of 2014.

\section{Family Cunaxidae}

This family included one species Cunaxa sp., which was isolated from animal feed collected from Nasr City and Kafr El-Hema by a few numbers during the whole year of 2014 .

\section{Family Tarsonemidae}

The tarsonemid mites have bean reported by several investigators, from Egypt (Taha, 1985), in England (Hughes, 1976), Canada (Sinha and Wallace, 1966). This family included one species Tarsonemus sp., which was isolated from grain, faba bean and pea collected from Nawag and Kafr El-Hema by intermediate numbers during the whole year of 2014 .

\section{Family Cheyletidae}

Work on the cheyletid mites has also been done by other workers in Egypt. El-Badry et al. (1980) reported that the extensive distribution of the cheyletid mites have been seen not only in Egypt but also abroad. Hughes, 1976 mentioned that the cheyletid mites are generally found associated with acarid mites in granaries, warehouses, beans and also in the leaf-litter, and top soil inhabited by different kinds of micro arthropods. This family was represented by six species as

- Cheyletus malaccensis was isolated from flour, rice and grain collected from Nasr City and Sammanoud by intermediate numbers during the whole year of 2014.

- Cheyletus fortis was isolated from grain and animal feed collected from Nasr City and Nawag by rare numbers during the whole year of 2014 .

- Cheyletus eruditus was isolated from maize, flour and wheat collected from Sammanoud and Kafr El-Hema by few numbers all the period of the study.

- Hemichetus bakeri was isolated from onion and wheat collected from Nawag by few numbers during all the period of the study.

- Chletomorpha sp. was isolated from animal feed and flour collected from Nasr City by intermediate numbers during all the period of the study.

- Ker bakeri was isolated from rice and faba bean collected from Nawag and Sammanoud by few numbers during the whole year of 2014.

\section{Family Stigmaeidae}

This family included three species, Stigmaeus africanus, was isolated from rice and wheat collected from Nasr City and Sammanoud by few numbers during the whole year of 2014. Agistimus exertus, was isolated from barley and garlic collected from Nawag and Nasr City by rare numbers during all the period of the study. Stigmus zaheri, was isolated from garlic and onion collected from Sammanoud by rare numbers during the whole year of 2014.

\section{B - Suborder Acaridida}

Obtained results are presented in Table (2).

\section{Family Acaridae}

The family was represented by 9 species, Tyrophagus putresentiae, it is noticeable that this mite species happens to be the commonest species of storage acari found in only 4 different sources, onion, barley, floor and rice collected from Sammanoud and Kafr El- Hema by dominant numbers during the period of study. In addition, it has been found in different sources outside Egypt Hughes, (1976) and Maurya and Jamil, (1982). Tyrophagous palmarum, was isolated by few numbers from three sources wheat, hay and rice, collected from Nasr City and Sammanoud during the two years (2013 and 2014). Tyrophagous longior, was isolated by intermediate numbers from wheat and flour collected from Sammanoud and Nawag during the summer seasons. Acarus siro, was isolated by few numbers from rice, barley and faba bean, collected from Nasr City throught the two years. Acarus farriers, is a field species but it was isolated by few numbers from floor and grain, collected from Sammanoud during all the period of study. Caloglyphus rizoglyphoides, was isolated from animal feed collected from Nasr City and Nawag by intermediate numbers during the summer and autum seasons. Caloglyphus berlesi, was isolated by intermediate numbers from three sources wheat, grain and flour collected from Nawag and Sammanoud during all the period of the study.

Incidence of the mite species has also been reported by Hughes, (1976) and Sinha et al. (1979). Caloglyphus mycophagous, was isolated by intermediate numbers from wheat and grain, collected from Nawag and Sammanoud during all the period of the study. Rhizoglyphus robini, was isolated by intermediate numbers from onion and garlic, collected from Sammanoud during all the period of the study. Incidence of acarid mites had, been examined by many authors Hughes, (1976); 
Thind and Clark, (2001); Mohamed, (2003) and Abdel-Khalik, (2013).

\section{Family Suidasidae}

This family was represented by two species Suidasia nesbitti, which was isolated from flour, wheat and pea, collected from Sammanoud and Nawag by rare numbers during the period of the study. Also, Suidasia sp., which isolated from flour and maize, collected from Nawag and Kafr ElHema by rare numbers during the summer season.

\section{Family Carpoglyphidae}

This family was represented by one species Carpoglyphus sp., which was isolated from animal feed, collected from Nasr City by few numbers during all the study period.

Family Glycyphagidae

Glycyphagid mites has been also studied by Criffiths, (1960); Sinha and Wallace, (1966); Hughes, (1976); Attiah, (1969) and Taha, (1985).This family was represented by four species; Ctenoglyphus hughesi, which was isolated from flour and onion, collected from Nawag by a few numbers during the period of the study. Glycyphagus ornatus, was isolated from garlic and wheat, collected from Sammanoud and Nawag by rare numbers. Glycyphagus domesticus, was isolated from onion, flour and rice, collected from Nasr City and Sammanoud by a few numbers during the period of the study. Glycyphagus aegyptiacus, was isolated from flour, maize and faba bean, collected from
Sammanoud and Nawag by rare numbers during the summer season.

\section{Family Labidophoridae}

This family was represented two species Gohieria fusca, was isolated from maize and wheat, collected from Nawag by rare numbers during the summer season. Lebidoglyphus destructor, was isolated from garlic and onion, collected from Sammanoud and Nawag by few numbers during the summer season.

\section{Family Chortoglyphidae}

This family included one species Chortoglyphus sp., which was isolated from animal feed, collected from Nasr City and Nawag by a few numbers during the summer season only.

\section{C - Suborder Oribatida}

Obtained results are presented in Table (3).

\section{Family Oppiidae}

This family was included one species Oppia sp., which was isolated from animal feed, collected from Nasr City and Sammanoud by a few nmbers during the summer season. The studies on the incidence of storage mites have been reported by El- Sanady, (2005) and Abou- El Enien, (2011) in Egypt who recorded different mite species in different varieties of stored products. 
Table 1. Incidence of Order Parasitiformes, Suborder Gamasida mite species in Gharbia and Cairo Governorates for two years (2013 and 2014)

\begin{tabular}{|c|c|c|c|c|}
\hline \multicolumn{5}{|c|}{ Order : - Parasitiformes Suborder : - Gamasida } \\
\hline Family & Species & Habitat & Abundance & Locality \\
\hline \multirow{8}{*}{$\begin{array}{l}\text { Ascidae } \\
\text { Vogits and } \\
\text { Oudemans }\end{array}$} & $\begin{array}{l}\text { Proctolaelaps pygmaeus } \\
\text { Muller) }\end{array}$ & wheat -maize & + & Nawag _ Sammanoud \\
\hline & $\begin{array}{l}\text { Proctolaelaps bickleyi } \\
\text { Lindiqust and Hunter) }\end{array}$ & garlic - breadbean & + & Nawag - Sammanoud \\
\hline & Proctolaelaps cossi ( Evans) & $\begin{array}{lll}\text { animal feed } & - \\
\text { seeds } & & \\
\end{array}$ & + & Nawag- Kafr El-Hema \\
\hline & Lasioseius africanus Nasr & wheat -flour - rice & +++ & Nasr City - Nawag \\
\hline & $\begin{array}{l}\text { Lasioseius sewai Nasr and } \\
\text { Abou Awad }\end{array}$ & onion - corn- pea & + & Nawag - Sammanoud \\
\hline & Lasioseius aegypticus ( Afifi ) & wheat - grain & ++ & Nawag -Nasr City \\
\hline & Blattisocius keegani Fox & barley- faba bean & ++ & $\begin{array}{l}\text { Nawag -Sammanoud - } \\
\text { Nasr City }\end{array}$ \\
\hline & Blattisocius tarsalis (Berlese) & $\begin{array}{l}\text { barley }- \text { grain }- \\
\text { seeds }\end{array}$ & ++ & $\begin{array}{l}\text { Nawag - Kafr El- } \\
\text { Hema }\end{array}$ \\
\hline \multirow{2}{*}{$\begin{array}{l}\text { Ameroseiidae } \\
\text { Evans }\end{array}$} & $\begin{array}{l}\text { Kleemania kossi } \\
\text { and Nasr , Hafis }\end{array}$ & $\begin{array}{l}\text { corn }- \text { onion }- \\
\text { garlic }\end{array}$ & + & Nawag - Sammanoud \\
\hline & $\begin{array}{l}\text { Kleemania } \\
\text { (Oudemans) }\end{array}$ & $\begin{array}{l}\text { onion - maize - } \\
\text { bread bean }\end{array}$ & ++ & Nawag - Sammanoud \\
\hline $\begin{array}{l}\text { Rhodacaridae } \\
\text { Oudemans }\end{array}$ & Rhodacarus tabeeni & onion - rice - bean & + & Nasr City - Nawag \\
\hline \multirow[t]{2}{*}{$\begin{array}{l}\text { Digamaseilidae } \\
\text { Evans }\end{array}$} & $\begin{array}{l}\text { Dedroplaelaps aegypticus } \\
\text { (Metwally and Mersal) }\end{array}$ & $\begin{array}{l}\text { rice - wheat - } \\
\text { barley }\end{array}$ & + & $\begin{array}{llr}\text { Nasr city } & - \\
\text { Sammanoud - Kafr } & \text { El- } \\
\text { Hema } & \\
\end{array}$ \\
\hline & Dendrolaelaps rasmii & animal feed & + & Nasr City - Nawag \\
\hline Ologamasidae & Gamasiphis pulchellus & $\begin{array}{lll}\text { pea- } & \text { rice } & - \text { faba } \\
\text { bean } & & \\
\end{array}$ & ++ & Sammanoud- Nawag \\
\hline $\begin{array}{l}\text { Macrochelidae } \\
\text { Vitzithum } \\
\end{array}$ & $\begin{array}{l}\text { Macrocheles scutatus } \\
\text { Berlese ) }\end{array}$ & animal feed & ++ & Nawag- Kafr El-Hema \\
\hline $\begin{array}{l}\text { Parasitidae } \\
\text { Oudemans }\end{array}$ & $\begin{array}{l}\text { Parasitus consoginues ( Odu } \\
\text { and Vogits) }\end{array}$ & $\begin{array}{l}\text { animal feed } \\
\text { maize }\end{array}$ & ++ & Nawag \\
\hline
\end{tabular}


Table 2. Incidence of Order Acariformes, Suborder Acaridida mite species in Gharbia and Cairo Governorates for two years (2013 and 2014)

Order : - Acariformes Suborder : - Acaridida

\begin{tabular}{|c|c|c|c|c|}
\hline Family & Species & Habitat & Abundance & Locality \\
\hline \multirow{9}{*}{$\begin{array}{l}\text { Acaridae Ewing and } \\
\text { Nesbitt }\end{array}$} & $\begin{array}{l}\text { Tyrophagus } \\
\text { putrescentiae (Schrank) }\end{array}$ & $\begin{array}{l}\text { onion - barley - } \\
\text { floor - rice }\end{array}$ & ++++ & $\begin{array}{l}\text { Sammanoud- Kafr } \\
\text { El-Hema }\end{array}$ \\
\hline & $\begin{array}{l}\text { Tyrophagus palmarum } \\
\text { Oudemans }\end{array}$ & $\begin{array}{l}\text { wheat - hay - } \\
\text { rice }\end{array}$ & ++ & $\begin{array}{l}\text { Nasr City } \quad- \\
\text { Sammanoud }\end{array}$ \\
\hline & $\begin{array}{l}\text { Tyrophagous longior } \\
\text { (Gervais) }\end{array}$ & Wheat - flour & +++ & $\begin{array}{l}\text { Sammanoud } \\
\text { Nawag } \\
\end{array}$ \\
\hline & Acarus siro Linnaeus & $\begin{array}{l}\text { rice- barley-faba } \\
\text { bean }\end{array}$ & ++ & Nasr City \\
\hline & $\begin{array}{l}\text { Acarus } \\
\text { (Oudemans) }\end{array}$ & flour - grain & ++ & Sammanoud \\
\hline & $\begin{array}{l}\text { Caloglyphus } \\
\text { rhizoglyphoides } \\
\text { (Zachvatkin) }\end{array}$ & animal feed & +++ & Nasr City- Nawag \\
\hline & $\begin{array}{l}\text { Caloglyphus } \\
\text { berlesei(Michael) }\end{array}$ & $\begin{array}{l}\text { Wheat- grain- } \\
\text { flour }\end{array}$ & +++ & $\begin{array}{l}\text { Nawag- } \\
\text { Sammanoud }\end{array}$ \\
\hline & $\begin{array}{l}\text { Caloglyphus mycophagus } \\
\text { (Megnin) }\end{array}$ & Wheat - grain & +++ & $\begin{array}{l}\text { Nawag- } \\
\text { Sammanoud } \\
\end{array}$ \\
\hline & $\begin{array}{l}\text { Rizoglyphus robini } \\
\text { Claparede }\end{array}$ & onion - garlic & +++ & Sammanoud \\
\hline \multirow{2}{*}{ Suidasidae Attiah } & $\begin{array}{l}\text { Suidasia } \\
\text { Hughes }\end{array}$ & $\begin{array}{l}\text { flour - wheat - } \\
\text { pea }\end{array}$ & + & $\begin{array}{l}\text { Sammanoud- } \\
\text { Nawag }\end{array}$ \\
\hline & Suidasia sp. & flour -maize & + & $\begin{array}{l}\text { Nawag- Kafr El- } \\
\text { Hema }\end{array}$ \\
\hline $\begin{array}{l}\text { Carpoglyphidae } \\
\text { Oudemans }\end{array}$ & Carpoglyphus sp. & animal feed & ++ & Nasr City \\
\hline \multirow{4}{*}{$\begin{array}{l}\text { Glycyphagidae } \\
\text { Berlese }\end{array}$} & $\begin{array}{l}\text { Ctenoglyphus hughesi } \\
\text { Attiah }\end{array}$ & flour - onion & ++ & Nawag \\
\hline & $\begin{array}{l}\text { Glycyphagus ornatus } \\
\text { Kramer }\end{array}$ & garlic - wheat & + & $\begin{array}{l}\text { Sammanoud- } \\
\text { Nawag } \\
\end{array}$ \\
\hline & $\begin{array}{l}\text { Glycyphagus domesticus } \\
\text { (De-Geer) }\end{array}$ & $\begin{array}{l}\text { onion }- \text { flour - } \\
\text { rice }\end{array}$ & ++ & $\begin{array}{ll}\text { Nasr } & \text { City- } \\
\text { Sammanoud } & \\
\end{array}$ \\
\hline & $\begin{array}{l}\text { Glycyphagus aegyptiacus } \\
\text { Attiah }\end{array}$ & $\begin{array}{l}\text { flour - maize - } \\
\text { faba bean }\end{array}$ & + & $\begin{array}{l}\text { Sammanoud- } \\
\text { Nawag }\end{array}$ \\
\hline \multirow{2}{*}{$\begin{array}{l}\text { Labidophoridae } \\
\text { oudemans }\end{array}$} & $\begin{array}{l}\text { Lepidoglyphus destructor } \\
\text { (Schrank) }\end{array}$ & garlic-onion & ++ & $\begin{array}{l}\text { Sammanoud- } \\
\text { Nawag }\end{array}$ \\
\hline & $\begin{array}{ll}\begin{array}{l}\text { Gohieria } \\
\text { (Oudemans ) }\end{array} & \text { fusca } \\
\end{array}$ & maize - wheat & + & Nawag \\
\hline $\begin{array}{l}\text { Chortoglyphidae } \\
\text { Berlese }\end{array}$ & Chortoglyphus sp. & animal feed & ++ & Nasr City- Nawag \\
\hline
\end{tabular}


Table 3. Incidence of Order Acariformes, Suborder Actinidida mite species in Gharbia and Cairo Governorates for two years (2013 and 2014)

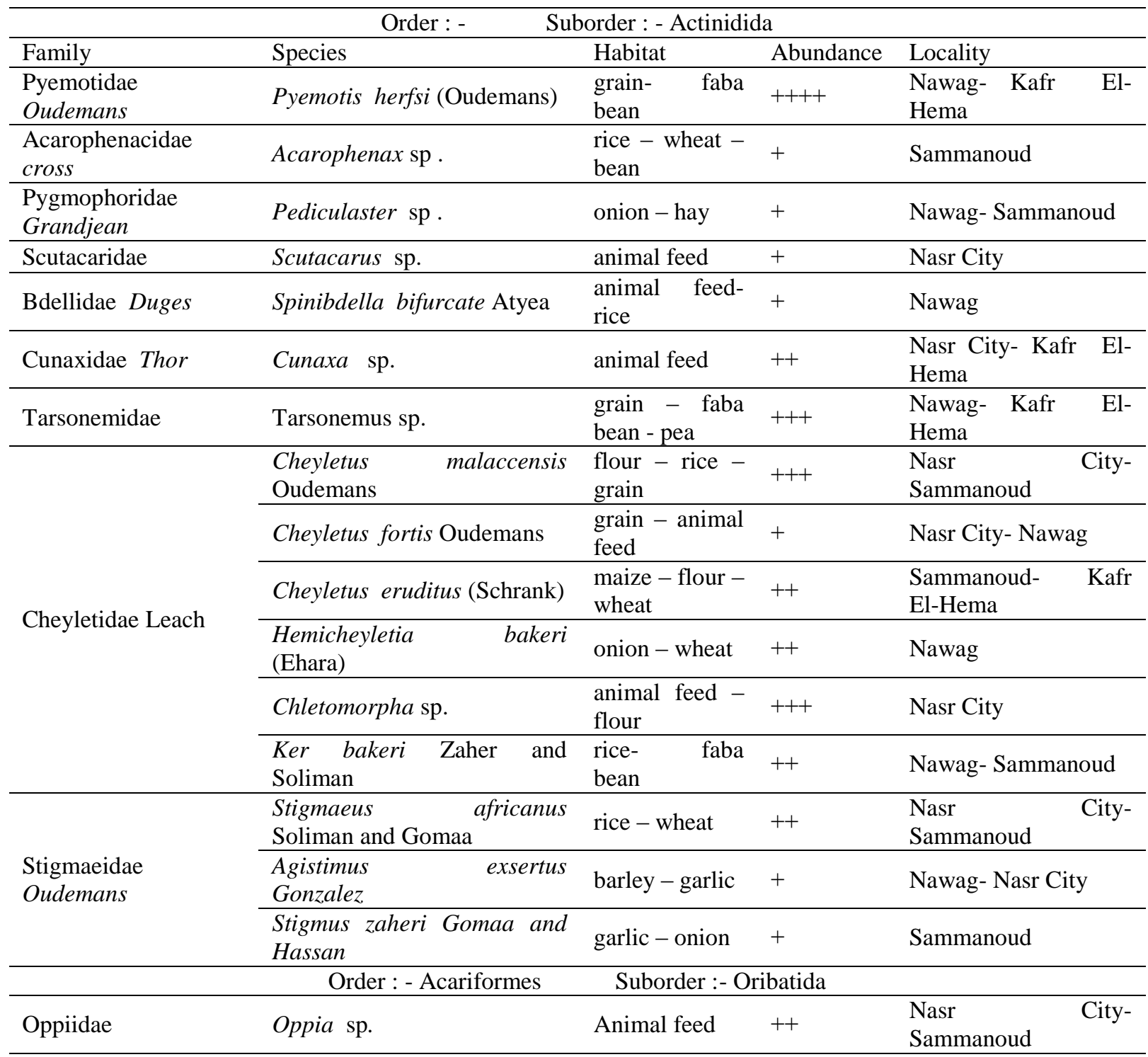

Dominant ++++: The mite species number forming more than $10 \%$ of total population.

Intermediate +++ :The mite species number forming between $5-10 \%$ of total population.

Few ++ : The mite species number forming between $2-5 \%$ of total population.

Rare + :The mite species number forming less than $\% 2$ of total population. 


\section{References}

Abdel - Khalik, Asmaa R. (2013). Studies on the effect of certain mites on some food products. M. Sc. Thesis, Fac. Sci., Menofia Univ., 104pp.

Abou El-Enien, N.F. (2011). Ecological and biological studies on some mites associated with some cereal and stored products at Dakahlia Governorate. M. Sc. Thesis, Fac. Sci., (Girls), AlAzhar Univ., pp.102.

Attiah, H.H. (1969). Tyroglyphid mites associated with stored food in Egypt. Tech. Bull., (10): 4-51.

El-Badry, M.A.; Rizk, G.N. and Hafez, S.M. (1980). Frequency of occurrence of predacious and parasitic mites inhabiting stored products. Mesopotamia J. Agric., 15 (1): 223 -234.

El-Sanady, Mariam, A. (2005). Studies on some stored product mites and their predators. Ph.D. Thesis, Fac, Sci., Al-Azhar Univ., 193 pp.

Griffiths, D.A. (1960). Mite pests of stored products. Ann. App.Biol., 46 (3): 123-130.

Gulati, R. and Mathur, S. (1995). Effect of Eucalyptus and Mentha leaves and Curcuma rhizomes on Tyrophagus putrescentiae (Schrank) (Acari: Acaridae) on wheat. Exp. \& Appl. Acarology. 19: 511-518.

Hughes, A. M. (1961). The mites of stored food. Min. of Agr., Fish. \&Food Tech. Bull., 9: 278.

Hughes, A. M. (1976). The mites of stored food products and houses. Tech. Bull., Min. Agric, and Fisheries in London, 9: 400 pp.

Krantz,G.W. (1978). A manual of Acarology, Oregon State Univ. Book stares Ltd., Coerallis, Oregon, 335pp.

Krantz, G.W. and Walter, D. E. (2009). A Manual of Acarology. Texas Tech Univ. Press, 807 pp.

Lindquist, E.E. and Evans, G.O. (1965). Taxonomic concepts in the Ascidae, with a modified setal nomenclature for the idiosoma of the Gamasina (Acarina: Mesostigmata). Mem. Ent. Soc. Can., 47: 1-64.

Maurya, K.R. and Jamil, Z. (1982). A survey of storage Acari in Lucknow, India. India Biol. Mem., 6 (2): 97-122.
Metwally , A.M.(1976). Ecological and biological studies on super family parasitoida in Mostorod Region. Ph.D. Thesis,Fac. of Agric., Al- Azhar univ., 166pp.

Mohamed - Azza, A. (2003).Studies on some mites associated with cereals and stored products in Egypt. M.Sc. Thesis, Fac.of Sci. (Girls), A1Azhar Univ., 103pp.

Riham - Taha, H. A. (2014). Biological studies on some granivorous mites belong to sub-order Acaridida. M. Sc. Thesis, Fac.of Sci., Girls, Al Azhnr Univ., 159 pp.

Sinha, R.N. and Wallace, H.A. (1966). Association of granary mites and seed-borne fungi in stored grain and in outdoor and indoor habitats. Ann. Eut. Soc. Am., 59: 1170-1181.

Sinha, R.N. and Wallace,H. A, (1977). Storage stability of farm stored rape- seed and barley. Can. J. Plant science, (5): $351-365$.

Sinha, R.N.; Wallace,H.A.H.; Mills, J.T. and Makenzie, R.I.H. (1979). Storability of farmstored hulless Oats in Manitoba.Can. J. Plant Sci., 59: 949-957.

Summers, F. M. and Price, D.W. (1970).Review of the mite family Cheyletidae. Univ. Calif Pubi. Entornol., 61: $153 \mathrm{p}$.

Taha, H.A. (1985). Morphological and biological studies on some mites associated with stored products. Ph.D. Thesis in Agrie. Zool. \& Nematol. Dept. Fac. Of Agric. Al-Azher Univ. $159 \mathrm{pp}$.

Thind, B. B. and Clarke, P. G. (2001). The occurrence of mites in cereal- based foods destined for human consumption and possible consequences of infestation. Exp AppI. Acarol, 25:203 -215.

Zaher, M.A.; Mohamed, M.l. and Abdel-Halim, S.M. (1984). Incidence of mites associated with stored seeds and food products in Upper Egypt. $17^{\text {th }}$ Int. Cong. Entomol. Hamburg. F. R. G. 460 pp 


\section{الأكاروسات المرتبطة بالمنتجات المخزونة}

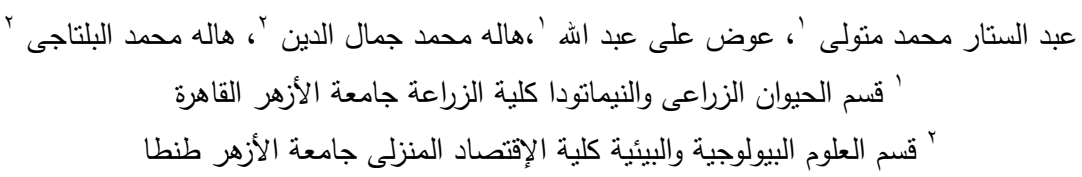

تهذف هذه الدراسة إلى تنجيل الأكاروسات التى تصيب بعض أنواع المواد الغذائية المخزونة وهى القمح والأرز والفول والذرة والثوم

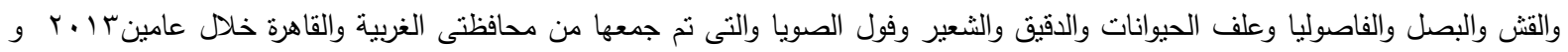

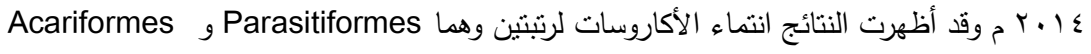

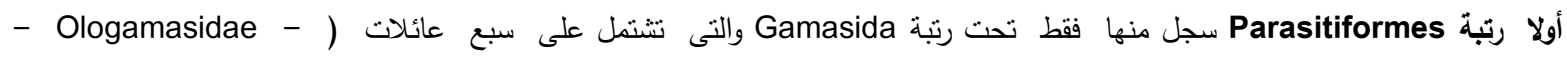
- Rhodacaridae - Ameroseiidae Ascidae - Macrochelidae - Parasitidae العائلات 17 نوع ، يتبعوا تسع أجناس. فعائلة ال Ascidae بها ثمانية أنواع ، وعائلة ال Ameroseiidae بها نوعين ، بينما عائلات

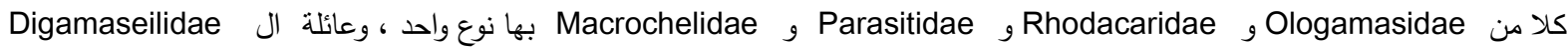

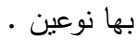

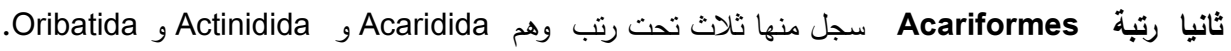

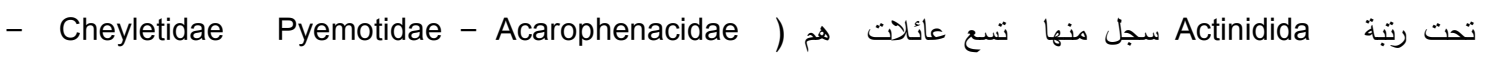
- Bdellidae - Pygmophoridae - Cunaxidae - Tarsonemidae (Stigmaeidae - Scutacaridae

- Carpoglyphidae - Suidasidae - Acaridae ( Aقد سجل منها سته عائلات Acaridida (Chortoglyphidae - Labidophoridae - Glycyphagidae وقد سجل من هذه العائلات تسعة عشر نوع وإحدى عشر جنس. بينما تحت رنبة Oribatida سجل منها عائلة واحدة Opiidae يتبعها نوع واحد. 